Vol. 1, No. 1, pp. 18-28, 2020

\title{
The GARCH Model Volatility of Sharia Stocks Associated Causality with Market Index
}

\author{
Endang Soeryana Hasbullah ${ }^{a^{*}}$, Endang Rusyaman ${ }^{\text {b }}$, Alit Kartiwa \\ ${ }^{a, b, c}$ Department of Mathematics, Faculty of Mathematics and Natural Sciences, Universitas Padjadjaran, \\ IINDONESIA
}

*Corresponding authoremail: endang.soeryana@unpad.ac.id; end.soeryana@gmail.com

\begin{abstract}
The purpose of this paper is to examine the volatility of Islamic stocks related to the causality of the composite stock price index (CSPI). The aim is to investigate the causality of several levels of stock returns with the movement of the CSPI, and determine its volatility as a measure of risk. To determine the causality relationship is done by using the granger causality test method, with Vector Autoregressive (VAR) modeling. Whereas to determine the volatility is done using the Generalized Autoregressive Conditional Heteroscedastisiy $(\mathrm{GARCH})$ model approach. The results of the causality test show that there is a direct relationship that affects and is influenced by the CSPI, and the relationship that affects each other between the company's stock market and the movement of the CSPI. While the volatility follows the GARCH model (1, 1). Based on the results of this study are expected to be used as consideration in making investment decisions in the analyzed stocks.
\end{abstract}

Keywords: Stock Returns, Vrenger Causality, VAR Models, GARCH Models

\section{Introduction}

The capital market in Indonesia began to develop into an Islamic capital market since July 3, 1997, PT. Denareksa Investment Management launches Sharia Mutual Funds. Indonesia Stock Exchange in cooperation with PT. Denareksa Investment Management launched the Jakarta Islamic Index (JII) on July 3, 2000. The Islamic capital market aims to guide investors who want to invest their funds in a sharia manner. Of course, shares traded on the Islamic capital market are shares that do not conflict with Islamic regulations (Aziz and Kurniawan, 2007).

In investment theory, each share will produce a return and risk (kalfin et al, 2019). Return is the result obtained from the investment or the level of profit enjoyed by the investor, for an investment 
made (Kalfin et al, 2019). The formation of stock prices occurs because of the demand and supply for these shares. In other words, the price is formed by the supply and demand of these stocks. The supply and demand occurs because of many factors, both specific to shares and macro factors such as interest rates, inflation, exchange rates and non-economic factors such as social and political conditions, and other factors (Aziz and Kurniawan, 2007).

Stocks are securities that have a high level of risk. Risk or loss cannot be eliminated in investing, and this risk can be seen from the high and low levels of fluctuations (volatility) of stock prices. Therefore, to find out the level of risk it is necessary to know the relationship of what factors influence it, and how much influence. Macro variables such as interest rates and exchange rates always affect systematic risk on every investment, especially investments in each stock, both ordinary shares and sharia shares (Chapakia and Sanrego, 2007; Constantinou et al, 2004).

Based on the description above, this research will analyze the level of stock price volatility that has a causal relationship between the price index of sharia stock prices with the Generalized Autoregressive Conditional Heteroscedastic (GARCH) model approach.

\section{Methodology}

The analytical method in this paper is outlined in the following stages:

Data transformation. For example $X_{t}$ the closing value of the Composite Stock Price Index at time $t$ where $t=1,2, \ldots, T$ with $\mathrm{T}$ the amount of data observations. For example, also $X_{t}$ closing return of JCI country $i$ at time $t$, the return value can be calculated by equation (Tsay, 2005):

$$
X_{t}=\operatorname{In}\left(\frac{X_{t}}{X_{t-1}}\right)
$$

Stationary Test Data. The time series data stationary testing for the sharia stock return variables of several large companies and the Composite Stock Price Index return used in this study uses the Augmented Dickey Fuller test (ADF) with the help of Eviews 8. The hypothesis used is $H_{0}: A D F_{\text {test }}>$ MacKinnon Critical Value (there is a unit root), and $H_{1}: A D F_{\text {test }}<$ MacKinnon Critical Value (no root unit). Where the test criteria are starting $H_{0}$ if the $t$-statistic value of the ADF test is smaller than the $p$-value at each percentage level (Deng, 2004; Tsay, 2005).

Granger causality test. After the data is declared stationary, a granger causality test is performed to see the causal relationship between the movement of the Composite Stock Price Index and several sharia stock prices of large companies in Indonesia using Eviews 8 software. The hypothesis used is that $H_{0}: P_{i t}$ does not affect $X_{t}$ and $H_{1}: P_{i t}$ affects $X_{t}$. Test statistics seen from the value of the probability of the $\mathrm{F}$ test, where the criteria for testing results reject $H_{0}$ if the test probability $F<\alpha=5 \%$. If there is a direct but not simultaneous relationship then proceed to the next stage, and if there is a direct and simultaneous relationship then proceed to the VAR modeling stage (Constantinou et al, 2004; Wo'zniak, 2009).

Grouping data into regression models. Data were grouped from the results of the granger causality test for direct but not simultaneous relationships. Then proceed to the next stage.

Autocorrelation Test. To see the form of the relationship between the CSPI and the company an approach was made using a regression model to see patterns of relationships with the Jakarta CSPI movement. The hypothesis used is $H_{0}$ : There is no serial correlation on residuals, and $H_{1}$ : There is a serial correlation on residuals. The test statistic is seen from the Watson durbin value approaching 2, where the criterion of the result of testing is $H_{0}$ if the value is $\mathrm{DW} \leq 2$ (Tsay, 2005). 
Heteroscedasticity Test. After autocorrelation testing, hetroskedastis testing is performed to analyze the variance of errors. The hypothesis used is $H_{0}$ : Assumption of homoscedasticity of the error component is fulfilled, and $H_{1}$ : error is heteroscedastic. Test statistics seen from the probability value $\mathrm{Obs} * R$-Squared ( $p$-value), where the criteria for testing results reject $H_{0}$ if $p-$ value $\leq 5 \%$.

ARCH / GARCH model estimation. To solve the heteroscedastic problem, an estimation is performed with the ARCH or GARCH models. In the GARCH model, the parameter values are estimated in the same way in estimating the regression model. In general, estimating a GARCH model cannot be done just once. A number of trials are needed in forming the GARCH model in such a way that a coefficient of parameters that meets the required and significant requirements is obtained (Deng, 2004; Wo’zniak, 2009).

Partial and Total Verification Test. After selecting the best variance model, just like the next model the variance model needs to be done $t$-stat test to determine the significance of each independent variable in influencing the dependent variable.

- constant test $\alpha_{0}$, with hypotheses $H_{0}: \alpha_{0}=0$ and $H_{1}: \alpha_{0} \neq 0$. Where the test statistics are

$$
t_{\text {rasio }}=\frac{\alpha_{0}}{S . E \alpha_{0}}
$$

or prob value $\left(t_{\text {rasio }}\right)$. The test criteria, reject $H_{0}$ if $t_{\text {rasio }}>t_{\alpha}$ or probability $\left(t_{\text {rasio }}\right)<\alpha$ (Tsay, 2005).

- Coefficient Test $\boldsymbol{\alpha}_{\boldsymbol{i}}$, with hypotheses $H_{0}: \alpha_{i}=0$ and $H_{1}$ : There is $\alpha_{i} \neq 0$ Where the test statistics are

$$
t_{\text {rasio }}=\frac{\alpha_{i}}{S . E \alpha_{i}}
$$

or probability value $\left(t_{\text {rasio }}\right)$. Test criteria, reject $H O$ if $t_{\text {rasio }}>t_{\alpha}$ or $\left(t_{\text {rasio }}\right)<\alpha$ probability value (Tsay, 2005).

ARCH / GARCH model diagnostic test. To define the GARCH model properly, residuals must be standardized as follows:

$$
Z_{t}=\frac{\varepsilon_{t}}{\sigma_{t}}
$$

If the model is suitable, then the series $\left\{\varepsilon_{t}\right\}$ does not contain the ARCH effect and the squared residuals of $\left\{\varepsilon_{t}\right\}$ are white noise, which means the squared residuals of $\left\{\varepsilon_{t}\right\}$ must be independent (uncorrelated) and normally distributed with an average approaching $(\mu=0)$ and standards deviation $\sigma$. Meanwhile, to test whether the series $\left\{\varepsilon_{t}\right\}$ is white noise, it can be done by looking at the value of Q $(m)$ Ljung-Box (Febrian and Herwany, 2009; Deng, 2004; Tsay, 2005).

VAR modeling. VAR model is an autoregressive (AR) model development. If the AR of the current observation is influenced by previous observations of the data, then the VAR mode of time observation is influenced by previous observations of the data and other data. The VAR model with the order P is denoted VAR (P) expressed in the following equation (Tsay, 2005; Wo'zniak, 2009).

$$
Z_{t}=\phi_{t} Z_{t-1}+\ldots+\phi_{p} Z_{t-p}+a_{t}
$$

where residual $a_{t}$ is assumed to be white noise [4], (Tsay, 2005). 


\section{Results and Discussion}

\subsection{Analyzed Data}

The data used in this study are secondary data taken from www.finance.yahoo.com. For closing prices of Astra Graphia (ASGR) sharia shares, Bank Central Asia (BBCA), Citra Development (CTRA), Jasa Marga (JSMR), Indonesian Telecommunications (TLKM), Unilever Indonesia (UNVR), and the Composite Stock Price Index (CSPI) ). The data is daily data from January 4, 2010 to December 30, 2013.

\subsection{Data Analysis}

As explained in section 2, the analysis methodology is carried out in stages as follows:

Data transformation. Data transformation is performed to calculate the return value in each company stock, for example the JCI data which is denoted by variable $x$ has a close price on January 4,2010 that is Rp.2575.41 and on January 5, 2010 that is Rp.2605.28 using the equation (1) the calculation results are:

$$
x_{1}=\ln \frac{2605,28}{2575,41}=0,011531
$$

And so on to calculate the JCI return until the last data and carried out the same way for the variable $p_{1}$ is the ASGR stock price return, $p_{2}$ is the BCA stock price return, $p_{3}$ is the CTRA stock price return, $p_{4}$ is the JSMR stock price return, $p_{5}$ is the TLKM stock price return, $p_{6}$ is the return of the UNVR stock price.

Stationary test results of the data. The results of the data return stationary test for each sham and CSPI are given in Table 1 as follows.

Tabel 1: Stationary Test Results of Stock Returns and CSPI

\begin{tabular}{|c|c|c|c|c|c|c|}
\hline \multirow{2}{*}{ Variable } & \multicolumn{3}{|c|}{ Critical Value at the level: } & \multirow{2}{*}{$\begin{array}{c}A D F_{\text {test }} \\
\text { value }\end{array}$} & \multirow{2}{*}{ Prob. } & \multirow{2}{*}{ Conclusion } \\
\hline & $1 \%$ & $5 \%$ & $10 \%$ & & & \\
\hline$x$ & $-3,967547$ & $-3,414458$ & $-3,129363$ & $-18,53363$ & 0,0000 & $H_{0}$ rejected \\
\hline$p_{1}$ & $-3,967567$ & $-3,414468$ & $-3,129369$ & $-20,55699$ & 0,0000 & $H_{0}$ rejected \\
\hline$p_{2}$ & $-3,967518$ & $-3,414444$ & $-3,129355$ & $-35,11327$ & 0,0000 & $H_{0}$ rejected \\
\hline$p_{3}$ & $-3,967518$ & $-3,414444$ & $-3,129355$ & $-31,58663$ & 0,0000 & $H_{0}$ rejected \\
\hline$p_{4}$ & $-3,967547$ & $-3,414458$ & $-3,129363$ & $-18,83595$ & 0,0000 & $H_{0}$ rejected \\
\hline$p_{5}$ & $-3,967547$ & $-3,414458$ & $-3,129363$ & $-19,37230$ & 0,0000 & $H_{0}$ rejected \\
\hline$p_{6}$ & $-3,967528$ & $-3,414448$ & $-3,129358$ & $-28,46386$ & 0,0000 & $H_{0}$ rejected \\
\hline
\end{tabular}

Based on the table above it can be seen that the results of MacKinnon Critical Value for all observations of data, then all observations of data used are stationary in levels at the significance level of $1 \%, 5 \%$, and $10 \%$. To test the data, a significance level of $5 \%$ is chosen for each data test.

Granger causality test results. The results of testing the relationship between granger causality to the returns of Islamic stocks with CSPI, which is done using Eviews 8 software are given in Table-2 as follows. 
Based on the results of the table above, it is found that the variables $p_{1}, p_{2}, p_{3}$, are influenced by the variable $x$, for the variable $p_{4}, p_{5}$ affects the variable $x$, while for the variable $p_{6}$ has a simultaneous direct relationship with the variable $x$.

Table 2: Granger Causality Test Results

\begin{tabular}{ccc}
\hline$H_{0}$ & $F_{\text {-Statistik }}$ & Prob. \\
\hline$x$ does not affect $p_{1}$ & 2,68344 & 0,0456 \\
$p_{1}$ does not affect $x$ & 1,10896 & 0,3445 \\
$x$ does not affect $p_{2}$ & 7,63669 & 0,0005 \\
$p_{2}$ does not affect $x$ & 0,35919 & 0,6983 \\
$x$ does not affect $p_{3}$ & 5,67384 & 0,0032 \\
$p_{3}$ does not affect $x$ & 1,53225 & 0,2166 \\
$x$ does not affect $p_{4}$ & 1,38929 & 0,2446 \\
$p_{4}$ does not affect $x$ & 2,65791 & 0,0472 \\
$x$ does not affect $p_{5}$ & 0,25045 & 0,8610 \\
$p_{5}$ does not affect $x$ & 5,47552 & 0,0010 \\
$x$ does not affect $p_{6}$ & 3,57227 & 0,0285 \\
$p_{6}$ does not affect $x$ & 3,81651 & 0,0223 \\
\hline
\end{tabular}

The results of grouping data in a regression model. From the results of granger causality testing, the variables p1, p2, p3 can be grouped into the first group and the variables p4, p5 can be grouped into the second group, and both groups are modeled with a regression model.

\subsection{The First Group Regression Model}

Based on the causality test in which large companies do not have a simultaneous relationship with the movement of the Jakarta CSPI shares. The output of the regression model for the variables affected by the CSPI can be seen in Table-3 below.

Table 3: Output of Regression model output

\begin{tabular}{|c|c|c|c|c|}
\hline Variable & Coefficient & Std. Error & t-Statistic & Prob. \\
\hline P1 & 0.004009 & 0.001573 & 2.548110 & 0.0110 \\
\hline P2 & 0.435058 & 0.014452 & 30.10416 & 0.0000 \\
\hline P3 & 0.020427 & 0.007166 & 2.850658 & 0.0045 \\
\hline R-squared & 0.493390 & \multicolumn{2}{|c|}{ Mean dependent var } & 0.000521 \\
\hline Adjusted R-squared & 0.492345 & \multicolumn{2}{|c|}{ S.D. dependent var } & 0.012686 \\
\hline S.E. of regression & 0.009039 & \multicolumn{2}{|c|}{ Akaike info criterion } & -6.571562 \\
\hline Sum squared resid & 0.079244 & \multirow{2}{*}{\multicolumn{2}{|c|}{$\begin{array}{l}\text { Schwarz criterion } \\
\text { Hannan-Quinn criter. }\end{array}$}} & -6.556515 \\
\hline Log likelihood & 3200.065 & & & -6.565836 \\
\hline Durbin-Watson stat & 2.078638 & & & \\
\hline
\end{tabular}


Based on the results of the above output the equation is obtained:

(a) Autocorrelation Test Results

Based on the Results Table of the regression model above, the Durbin Watson value of 2.078638>2 means that there is no autocorrelation in the first group regression model.

(b) Heteroscedasticity Test Results

After autocorrelation testing, hetroskedastis testing is performed to analyze the variance of the error. To see the heteroscedasticity test results of each company can be seen in Table 4 below.

Based on the comparison of the standard error values for each method is different, but the coefficient test results with statistics show all the regression coefficients are significant, it can be concluded that heteroscedasticity is not a serious problem for this regression

Table 4: Comparison of Default Error Values

\begin{tabular}{ccc}
$\begin{array}{c}\text { Method } \\
\text { Variable }\end{array}$ & $\begin{array}{c}\text { Method } \\
\text { OLS }\end{array}$ & $\begin{array}{c}\text { Method } \\
\text { HC }\end{array}$ \\
\hline$p_{1}$ & 0,001573 & 0,000817 \\
$p_{2}$ & 0,014452 & 0,023649 \\
$p_{3}$ & 0,007166 & 0,009672 \\
\hline
\end{tabular}

\section{(c) ARCH / GARCH Model Estimation}

In the GARCH model, the parameter values are estimated in the same way in estimating the regression model. The results are given in Table 5 below.

Table 5: Estimation of the GARCH Model

\begin{tabular}{ccc}
\hline GARCH model & AIC value & SIC value \\
\hline GARCH $(1,1)$ & $-6,673605$ & $-6,643510$ \\
$\operatorname{GARCH}(1,2)$ & $-6,671646$ & $-6,636535$ \\
\hline
\end{tabular}

Based on the results in Table 5 above, it can be concluded that the best model used to model stocks in the first group is GARCH (2.1) because it has the smallest AIC and SIC values.

(d) Partial and Total Verification Test (Parameter Hypothesis Test)

After selecting the best model, then the chosen model needs to be t-stat tested to determine the significance of each independent variable in influencing the related variable. After conducting a partial test it can be concluded that constant $\alpha_{0}, \alpha_{1}$ influences the related variable $\left(\sigma_{t}^{2}\right)$ but the constant $\alpha_{2}, \beta_{1}$ does not affect the related variable $\left(\sigma_{t}^{2}\right)$.

Next, to find out whether or not there is a serial correlation in the model, re-testing the existence of the ARCH effect in the residual by using the ARCH-LM test. The results are given in Table 6 below. 
Table 6: ARCH-LM Test Results GARCH model $(1,1)$ Heteroskedasticity Test: ARCH

\begin{tabular}{llll}
\hline \hline F-statistic & & Prob. F(1,970) & 0.5847 \\
Obs*R-squared & 0.299402 & Prob. Chi-Square(1) & 0.5843 \\
\hline \hline
\end{tabular}

Based on Table- 6 the probability of Obs * R-squared is greater than the significance level of 0.05 (5\%). So it can be concluded that there has been no $\mathrm{ARCH}$ effect in stock residuals in the first group.

\section{(e) GARCH Model Diagnostic Test}

In the diagnostic test, the analysis that will be used is to perform Ljung-Box statistical tests and standardized ACF / PACF squared residual corelogram plots in Table 1 to see whether there are serial correlations or not in residuals.

From Figure-1 above it can be seen that ACF and PACF are not significant, which is indicated by the probability value of the Ljung-Box statistic that is greater than the confidence level of $0.05(5 \%)$ so that it can be concluded that the residuals of the model are white noise and not there is a serial correlation in residuals.

Table 7: Standardized Residual Squared Correlogram

\begin{tabular}{|c|c|c|c|c|c|c|}
\hline \multicolumn{7}{|c|}{ Correlogram of Standardized Residuals Squared } \\
\hline \multicolumn{7}{|c|}{$\begin{array}{l}\text { Date: } 05 / 13 / 14 \text { Time: } 15: 21 \\
\text { Sample: } 1973 \\
\text { Included observations: } 973\end{array}$} \\
\hline Autocorrelation & Partial Correlation & & $A C$ & PAC & Q-Stat & Prob* $^{*}$ \\
\hline 中 & i & 1 & -0.018 & -0.018 & 0.3006 & 0.583 \\
\hline 中 & 中 & & 0.014 & 0.014 & 0.5058 & 0.777 \\
\hline 㠼 & 㠼 & & 0.042 & 0.043 & 2.2679 & 0.519 \\
\hline di & di & & -0.030 & -0.029 & 3.1417 & 0.534 \\
\hline di & di & & -0.028 & -0.030 & 3.8994 & 0.564 \\
\hline 小 & 川 & & -0.006 & -0.008 & 3.9378 & 0.685 \\
\hline 㠼 & 吊 & 7 & 0.063 & 0.066 & 7.7931 & 0.351 \\
\hline$\sqrt{1}$ & 少 & 8 & 0.005 & 0.009 & 7.8197 & 0.451 \\
\hline 小 & 11 & 9 & 0.006 & 0.003 & 7.8535 & 0.549 \\
\hline 小 & 11 & 10 & 0.003 & -0.004 & 7.8607 & 0.642 \\
\hline | & | & 11 & -0.008 & -0.005 & 7.9223 & 0.720 \\
\hline$\|$ & $\|$ & 12 & -0.024 & -0.021 & 8.4992 & 0.745 \\
\hline d & d & 13 & -0.044 & -0.043 & 10.371 & 0.663 \\
\hline 中 & 11 & 14 & 0.011 & 0.007 & 10.482 & 0.726 \\
\hline$\|$ & 川 & 15 & -0.019 & -0.017 & 10.850 & 0.763 \\
\hline "1 & "1 & 16 & -0.012 & -0.012 & 11.002 & 0.809 \\
\hline$\|_{1}$ & $\|_{1}$ & 17 & 0.000 & -0.004 & 11.002 & 0.856 \\
\hline 中 & ip & 18 & 0.034 & 0.035 & 12.177 & 0.838 \\
\hline d & d & 19 & -0.037 & -0.033 & 13.528 & 0.811 \\
\hline 㠼 & 中 & 20 & 0.066 & 0.069 & 17.867 & 0.596 \\
\hline 川 & 山 & 21 & -0.022 & -0.023 & 18.331 & 0.628 \\
\hline d & d & 22 & -0.058 & -0.054 & 21.697 & 0.478 \\
\hline 11 & 11 & 23 & -0.001 & -0.007 & 21.699 & 0.538 \\
\hline$d_{1}$ & di & 24 & -0.033 & -0.027 & 22.764 & 0.534 \\
\hline
\end{tabular}

White noise test can also be done by testing the assumption of normality of residuals. The test was carried out with the help of Eviews 8 software, and the results are shown in Figure 1 as follows 


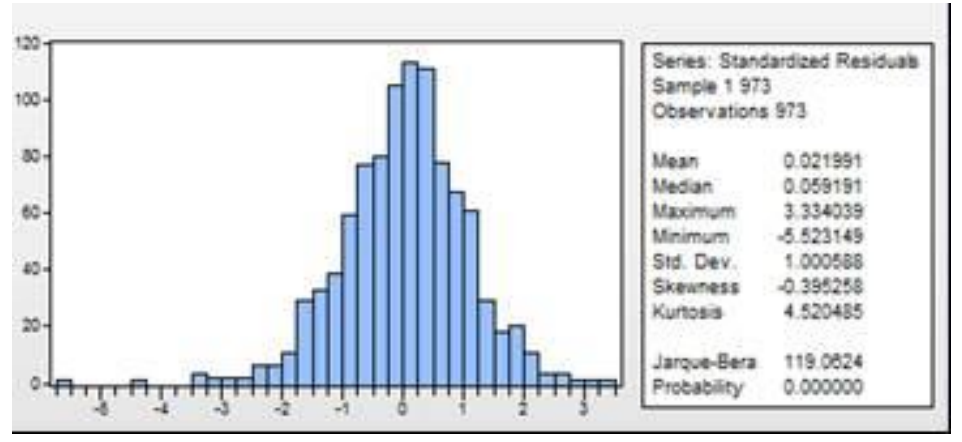

Figure 1: GARCH Model Residual Histogram $(2,1)$

In Figure 1, the histogram shows that the residuals are normally distributed. This is shown by: (a) the graph that follows the bell curve, and (b) the statistical value of Jarque-Bera which has a very large probability.

So, from the diagnostic test it can be concluded that the GARCH model $(2,1)$ is white noise and normally distributed. So that the GARCH $(2,1)$ model is good enough to be used in the modeling of stock data in the first group, with the GARCH $(2,1)$ equation as follows:

$X_{t}=0,005578 p_{1 t}+0,371095 p_{2 t}+0,020058 p_{3 t}+e_{t}$.

$\sigma_{t}^{2}=0,00000421+0,096757 e_{t-1}^{2}+0,013481 e_{t-1}^{2}+0,839765 \sigma_{t-1}^{2}$.

\subsection{Second Group Regression Model}

Based on causality testing in which large companies do not have a simultaneous relationship with the JCI movement. The results of the regression model output for variables affected by the CSPI can be seen in Table 8 below.

Based on the above output results obtained equation: $X_{t}=\beta_{1} p_{4 t}+\beta_{2} p_{5 t}$. Then do the research with the same steps for all stages in the second group, the GARCH equation $(1,1)$ is obtained as the best model for modeling sharia stock data in the second group, with the GARCH model equation $(1,1)$ as follows:

$X_{t}=0,102165 p_{4 t}+0,2843321 p_{5 t}+e_{t}$.

$\sigma_{t}^{2}=0,00000464+0,145702 e_{t-1}^{2}+0,817790 \sigma_{t-1}^{2}$.

Table 8: Results of Regression model output

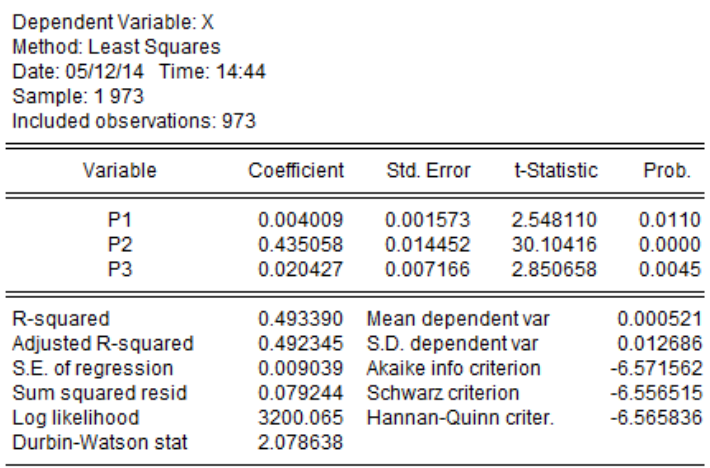




\subsection{VAR Modeling Results}

As has been proven in the causality test that between variables and have a two-way and simultaneous relationship, the model used to describe the relationship between the two capital markets uses the VAR model. The results are given in the following Table 9

\begin{tabular}{|c|c|c|}
\hline \multicolumn{3}{|c|}{$\begin{array}{l}\text { Vector Autoregression Estimates } \\
\text { Date: } 03 / 26 / 14 \text { Time: } 08: 15 \\
\text { Sample (adjusted): } 3973 \\
\text { Included observations: } 971 \text { after adjustments } \\
\text { Standard errors in () \& t-statistics in [ ] }\end{array}$} \\
\hline & $x$ & P6 \\
\hline$X(-1)$ & $\begin{array}{c}0.031558 \\
(0.03206) \\
{[0.98436]}\end{array}$ & $\begin{array}{r}-0.148022 \\
(0.07351) \\
{[-2.01350]}\end{array}$ \\
\hline$x(-2)$ & $\begin{array}{c}0.041050 \\
(0.03212) \\
{[1.27806]}\end{array}$ & $\begin{array}{r}-0.124549 \\
(0.07365) \\
{[-1.69112]}\end{array}$ \\
\hline$P 6(-1)$ & $\begin{array}{r}0.020673 \\
(0.01389) \\
{[1.48881]}\end{array}$ & $\begin{array}{r}-0.313519 \\
(0.03184) \\
{[-9.84680]}\end{array}$ \\
\hline$P 6(-2)$ & $\begin{array}{c}0.036679 \\
(0.01387) \\
{[2.64514]}\end{array}$ & $\begin{array}{r}-0.137784 \\
(0.03180) \\
{[-4.33324]}\end{array}$ \\
\hline c & $\begin{array}{c}0.000424 \\
(0.00041) \\
{[1.04089]}\end{array}$ & $\begin{array}{r}0.001419 \\
(0.00093) \\
{[1.51946]}\end{array}$ \\
\hline
\end{tabular}

From Table 9 above, modeling can be carried out as follows:

$$
\begin{aligned}
& x=0,000424+0,031558 x_{t-1}+0,041050 x_{t-2}+0,020673 p_{6 \cdot t-1}+0,036679 p_{6 \cdot t-2} \\
& p_{6}=0,001419-0,148022 x_{t-1}-0,124549 x_{t-2}-0,313519 p_{6 \cdot t-1}-0,137784 p_{6 \cdot t-2}
\end{aligned}
$$

\section{Conclusion}

In this paper, a study of the volatility of sharia shares related to the causality of joint stock price index (CSPI) has been carried out. The results of the study showed that the equation model for the first group obtained the GARCH model (2.1), namely the upward movement of the JCI was influenced by the movement of PT.Astra Graphia Tbk companies by a point, the company PT Bank Central Asia Tbk by a point, and PT. Citra Development Tbk amounted to a point. For the second equation model, the GARCH model (1.1) is obtained, namely Jakarta's JCI movement increased by PT. Jasa Marga Tbk's influence by a point, and PT. Telekomunikasi Indonesia Tbk amounted to a 
point. While Jakarta Composite Index and PT Unilever have simultaneous relationship with the proportional movement, if IHSG rises, PT. Unilever also experiences an increase and vice versa.

\section{References}

Aziz, H.A. and Kurniawan, T. Modelling the Volatility of Shari'ah Index: vidence from Kuala Lumpur Shari'ah Index (KLSI) and The Jakarta Islamic Index (JII). The International Conference on Islamic Capital Market: Regulation Products and Practise with Relevance to Islamic Banking and Finance. Jakarta: Muamalat Institute - IRTI IDB, 2007.

Chapakia, H. and Sanrego, Y.D. An Empirical Analisys of Islamic Stock Return in Malaysia. The International Conference on Islamic Capital Market: Regulation Products and Practise with Relevance to Islamic Banking and Finance. Jakarta: Muamalat Institute - IRTI IDB, 2007.

Constantinou, E., Georgiades,R., Kazandjian, A., and Kouretas, G.P., Mean and variance causality between the Cyprus Stock Exchange and major equities markets, Working Paper, Department of Accounting and Finance, The Philips College, 4-6 Lamias Street, CY-2100, Nicosia, Cyprus, 2004.

Deng, S.J. (2004). Heavy-Tailed GARCH models: Pricing and Risk Management Applications in Power Market, IMA Control \& Pricing in Communication \& Power Networks. 7-17 Mar http://www.ima.umn.edu/talks/.../deng/power_workshop_ima032004-deng.pdf.

Febrian, E. \& Herwany, A. Volatility Forecasting Models and Market Co-Integration: A Study on South-East Asian Markets. Working Paper in Economics and Development Studies. Department of Ekonomics, Padjadjaran University. 2009.

Kalfin, Sukono and Carnia, E. (2019). Optimization of the mean-absolute deviation portfolio investment in some mining stocks using the singular covariance matrix method. IOP Conf. Series: Journal of Physics: Conf. Series, 1315 (2019) 012002

Kalfin, Sukono and Carnia, E. (2019). Portfolio Optimization of the Mean-Absolute Deviation Model of Some Stocks using the Singular Covariance Matrix. International Journal of Recent Technology and Engineering (IJRTE), ISSN: 2277-3878, Volume-8, Issue-3.

Sifriyani. Vector Autoregressive dan Error Correction Modeling UntukMengestimasi Volume Perdagangan Saham. Jurnal EKSPONENSIAL Volume 2, Nomor 1, Mei 2011.

Tsay, R.S. Analysis of Financial Time Serie, Second Edition, USA: John Wiley \& Sons, Inc. 2005.

Wo'zniak, T., Granger Causal Analysis of VARMA-GARCH Models, Working Paper, Department 
of Economics, European University Institute, Via della Piazzuola 43, 50133 Florence, Italy, 2009. 